\title{
Gravity evidence of very thin crust at the Gakkel Ridge (Arctic Ocean)
}

\author{
Bernard J. Coakley *, James R. Cochran \\ Lamont-Doherty Earth Observatory of Columbia University, Palisades, NY 10964, USA
}

Received 9 February 1998; accepted 29 June 1998

\begin{abstract}
Gakkel Ridge, the active spreading center in the Arctic Ocean, is the slowest spreading portion of the global mid-ocean ridge system. Total spreading rates range from $0.6 \mathrm{~cm} / \mathrm{yr}$ in the east where the ridge disappears beneath the Laptev shelf to $1.3 \mathrm{~cm} / \mathrm{yr}$ in the west near Greenland. Bathymetry and gravity surveys of four sections of the Gakkel Ridge were carried out in 1996 by the U.S. Navy nuclear submarine USS POGY as part of SCICEX 96 in order to sample variations in seafloor morphology and gravity anomalies as a function of spreading rate. The ridge axis throughout the survey area is characterized by a continuous axial rift valley similar to that observed at other slow spreading ridges. The continuous rift axis suggests that well-organized seafloor spreading is occurring at total spreading rates of less than $1 \mathrm{~cm} / \mathrm{yr}$. In three faster spreading $(1.13-1.24 \mathrm{~cm} / \mathrm{yr})$ western survey areas located between $7^{\circ} \mathrm{E}$ and $54^{\circ} \mathrm{E}$, the Gakkel Ridge is deep compared with other ridge axes. Axial depths range between 4600 and $5100 \mathrm{~m}$ and ridge flanks at about $3200 \mathrm{~m}$. The ridge flank morphology is very blocky and is characterized by large scarps and deep fault-bounded troughs. Very large amplitude free-water anomalies with peak-to-trough amplitudes of $85-150 \mathrm{mGal}$ are observed centered on the axis of the Gakkel Ridge. Modeling of the free-water anomalies by varying the crustal thickness and average crustal density, including the gravity effect of the cooling of the mantle away from the axis, implies that if the average crustal density is less than 2900 $\mathrm{kg} / \mathrm{m}^{3}$, the crustal thickness must be less than $4 \mathrm{~km}$. The axial rift valley at the fourth survey area, near $98^{\circ} \mathrm{E}$ where the total spreading rate is $0.99 \mathrm{~cm} / \mathrm{yr}$, is buried by sediments. The axis in this region is associated with a continuous $70 \mathrm{mGal}$ gravity minimum implying the presence of a large buried rift valley. The rift flanks at $95^{\circ} \mathrm{E}$ are at a depth of greater than $3800 \mathrm{~m}, 600 \mathrm{~m}$ deeper than the average depth at the Gakkel Ridge axis west of $60^{\circ} \mathrm{E}$. Simple isostatic calculations suggest that the crust in this region may be vanishingly thin beneath the sediment cover. These observations indicate a relationship between melt production and seafloor spreading rate at very slow spreading rates, suggesting that ultra-slow spreading may suppress melt production or delivery at the Gakkel Ridge. (C) 1998 Elsevier Science B.V. All rights reserved.
\end{abstract}

Keywords: mid-ocean ridges; spreading centers; Arctic Ocean; gravity anomalies; gravity surveys; bathymetry

\section{Introduction}

Gakkel Ridge is an active mid-ocean ridge spreading center which extends for $\sim 1800 \mathrm{~km}$ across the Arctic Ocean through the center of the Eurasian

* Corresponding author. Tel.: +1 914365 8552; Fax: +1 914 365 8179; E-mail: bjc@1deo.columbia.edu
Basin from near the northeastern corner of Greenland to the Siberian continental shelf (Fig. 1). At its western end, Gakkel Ridge is connected via the Spitzbergen transform system to the Knipovich Ridge in the Norwegian Sea and thus to the MidAtlantic Ridge (MAR) (Fig. 1). At its eastern end, Gakkel Ridge continues into a broad zone of continental rifting on the Laptev Shelf [1]. Farther south, 


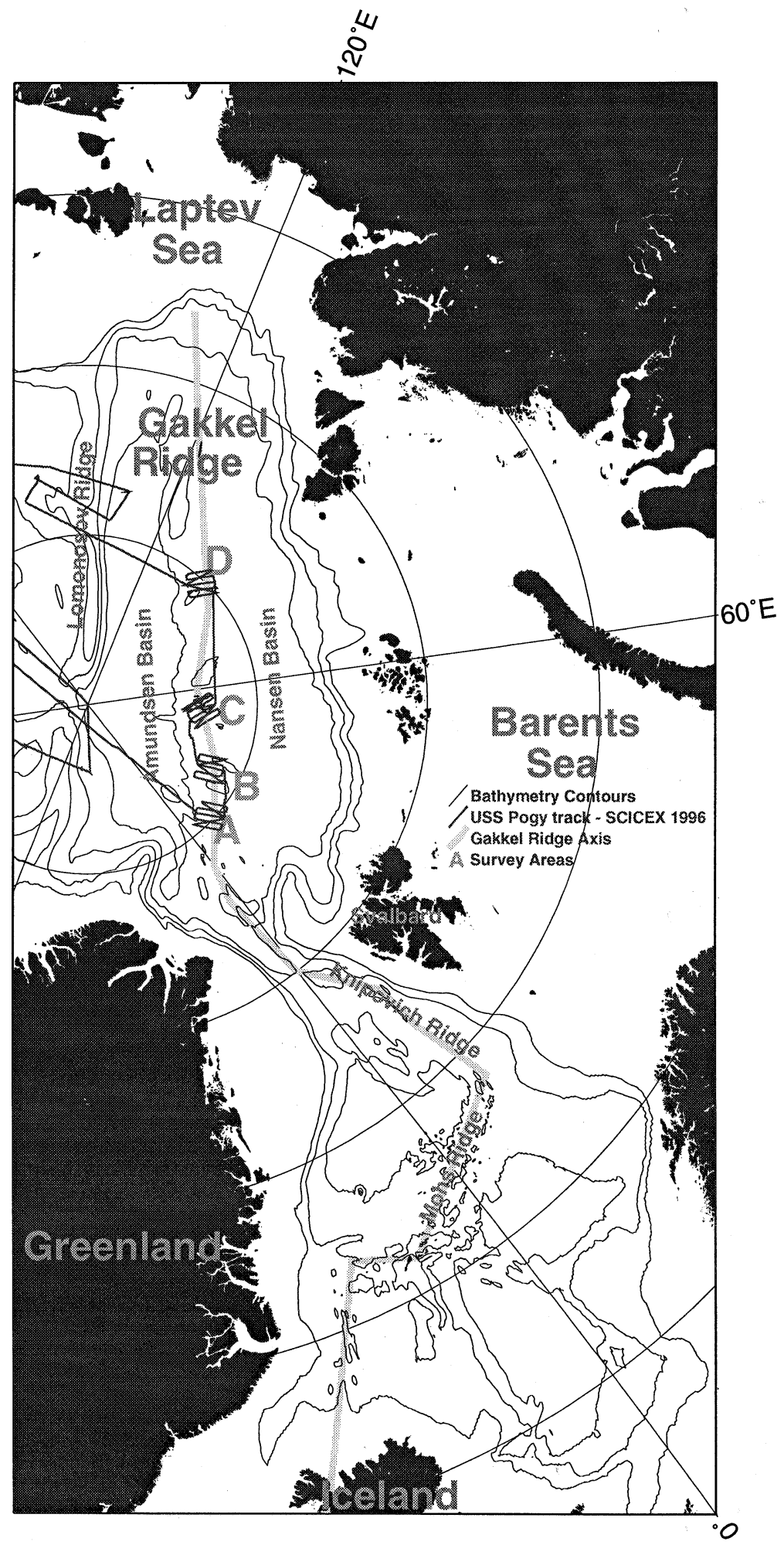



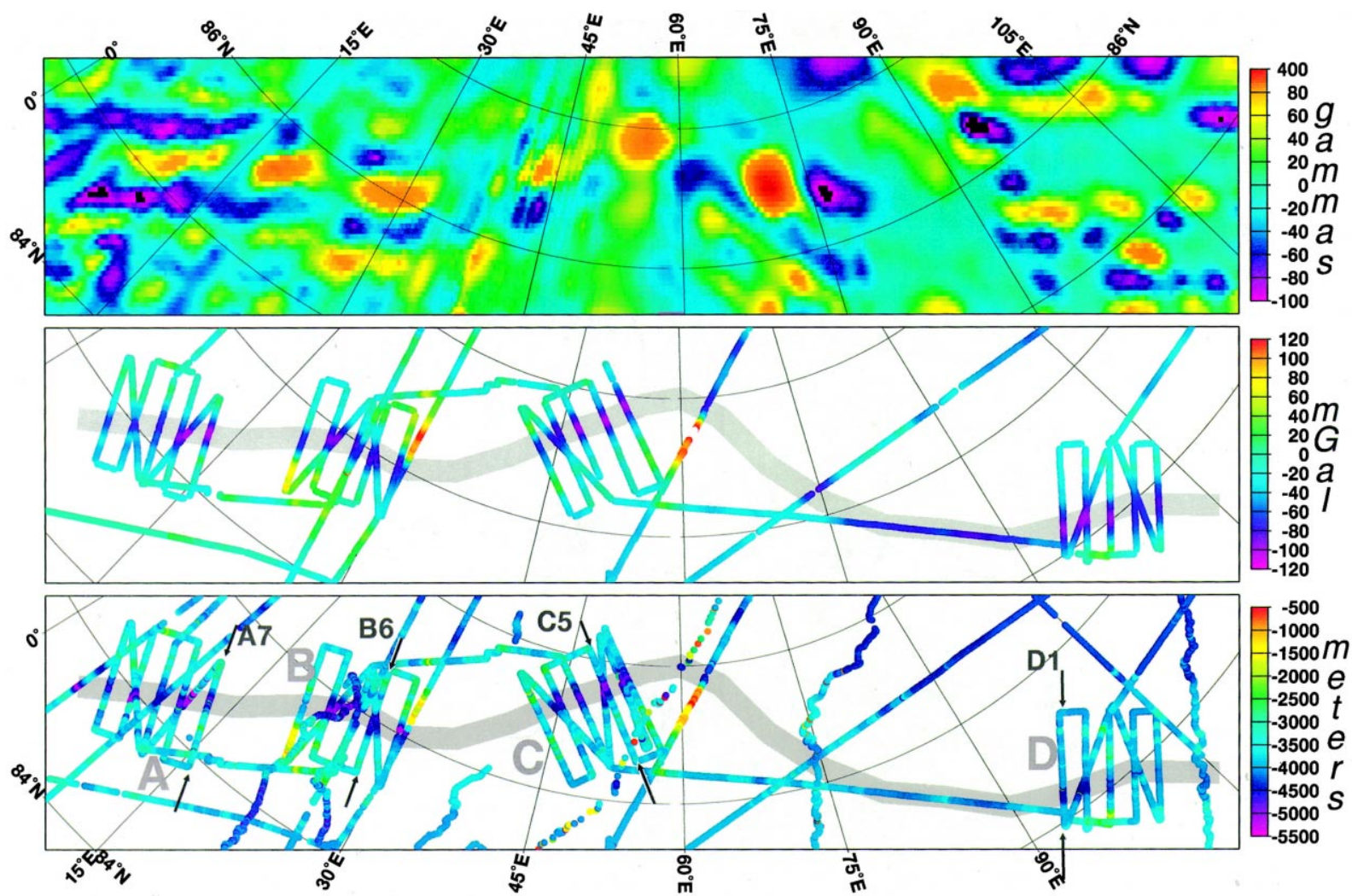

Fig. 2. (top) Aeromagnetic map of the Arctic Ocean in the area of the Gakkel Ridge axis. Data are from the Geological Survey of Canada compilation grid [42]. The ridge axis is marked by a linear high amplitude positive anomaly. The positive anomalies parallel to the axial anomaly at a distance of about $50 \mathrm{~km}$ on either side have been identified as Anomaly 5 with an age of $\sim 10$ Ma [2]. (center) Free-water gravity anomalies measured on SCICEX cruises in the vicinity of the Gakkel Ridge. The location of the ridge axis as determined from the bathymetry and gravity data is indicated in gray. (bottom) Bathymetry data from the vicinity of the Gakkel Ridge. The data were collected on U.S. Navy nuclear submarines during the SCICEX program, from icebreakers and from ice camps. The location of the ridge axis is noted in gray. The four surveys discussed in this paper are labeled and the locations of profiles displayed in Figs. 3-5 are indicated by arrows.

in Siberia, it approaches the North America-Eurasia pole of opening, losing its identity as a distinct plate boundary.

The Gakkel Ridge is the slowest spreading section of the global mid-ocean ridge system. Aeromagnetic data from the Eurasian Basin show banded seafloor spreading magnetic anomalies which have been dated [2,3]. Total spreading rates across the basin have been less than $1.5 \mathrm{~cm} / \mathrm{yr}$ since Anomaly
13 time ( $238 \mathrm{Ma})$ [2,3]. The Nuvel-1 global solution [4] gives present-day total opening rates which decrease from $1.33 \mathrm{~cm} / \mathrm{yr}$ at the western end of the ridge to $0.63 \mathrm{~cm} / \mathrm{yr}$ near the Laptev shelf, consistent with the aeromagnetic data. Continuous seafloor spreading magnetic anomalies can be traced across the basin (Fig. 2) to near the Laptev shelf $[5,6]$, which implies that some form of organized seafloor spreading is occurring even at these extremely low

Fig. 1. The northern end of the North America-Eurasia plate boundary, shown schematically by the gray line. The Gakkel Ridge extends across the Arctic Ocean from the northeastern corner of Greenland to the Laptev shelf. A narrow black line indicates the cruise tracks of the USS POGY, showing the location of the gravity and bathymetry surveys (A-D) collected from the submarine in 1996. Schematic contours (interval $=1000 \mathrm{~m}$ ) outline the major physiographic features that subdivide the Eurasian basin. 
spreading rates. Gravity anomalies derived from satellite altimetry data [7] are available for the easternmost portion of the Gakkel Ridge south of $81^{\circ} \mathrm{N}$. These data show a lineated negative anomaly characteristic of a slow spreading mid-ocean ridge crest extending up to the Siberian continental slope.

As the slow spreading end member of the midocean ridge system, the Gakkel Ridge constrains models of crustal genesis and the relationship between magmatic activity and tectonic extension in the development of oceanic crust. Models for the production of magma by decompression melting of passively upwelling mantle driven by plate separation predict a rapid decrease in crustal thickness at total spreading rates of less than about $1.5 \mathrm{~cm} / \mathrm{yr}$ $[8,9]$. It is generally accepted that, for total spreading rates greater than about $2 \mathrm{~cm} / \mathrm{yr}$, oceanic crust created away from hot spots has an average thickness of 6-7 km independent of spreading rate [9-12]. There is not a consensus on the average crustal thickness at extremely slow spreading ridges. Chen [11] concluded that the average crustal thickness remains about $6 \mathrm{~km}$ at all spreading rates, but that the range of variations in crustal thickness at very slow rates is much larger due to the increased frequency of transform faults at slow spreading ridges [13]. Bown and White [9] argue that crustal thickness at areas away from transforms decreases sharply at spreading rates of less than $1.5 \mathrm{~cm} / \mathrm{yr}$. However, many of their data for extremely slow spreading rates are from areas where seafloor spreading was just beginning or from dying ridges. The Gakkel Ridge presents an opportunity to examine the crustal thickness at a well-established steady-state extremely slow spreading ridge.

\section{New bathymetry and gravity data}

The first bathymetric profile across the Arctic Ocean was collected by the USS NAUTILUS in 1958 and published by Dietz and Shumway [14]. Their line included an oblique crossing of the Gakkel Ridge (referred to a "region of seamounts") at about $20^{\circ} \mathrm{E}$. Vogt et al. [2] showed 11 bathymetric profiles, some previously published by Johnson and Heezen [15] and Johnson [16], across the ridge axis obtained from U.S. and British nuclear submarines, most of them to the west of $20^{\circ} \mathrm{E}$. A few additional short profiles, again all to the west of $20^{\circ} \mathrm{E}$ appeared in Feden et al. [17]. The only published multibeam profiles across the Gakkel Ridge are two Hydrosweep lines, at $0^{\circ} \mathrm{E}$ and $56^{\circ} \mathrm{E}$, presented by Jokat et al. [18]. The published profiles from the western portion of the Gakkel Ridge show rough bathymetry and a deep axial valley typical of slow spreading ridges.

Since 1993, the U.S. Navy has made a series of nuclear submarine cruises to the Arctic Ocean for civilian scientific research through the SCICEX program. Geophysical instrumentation for these cruises has been restricted to a narrow-beam echo sounder and a Bell BGM-3 marine gravimeter [19]. During the 1996 cruise on USS POGY, bathymetry and gravity surveys were conducted of four areas on the Gakkel Ridge axis (Figs. 1 and 2) to examine variations in morphology and gravity anomalies as a function of spreading rate along the ridge. Each survey consisted of five $80-90 \mathrm{~km}$ long lines, oriented perpendicular to the axis at approximately 18 $\mathrm{km}$ spacings crossed by two diagonal tie-lines. Representative profiles from each survey are shown in Fig. 3. Total spreading rates for the survey areas calculated from the Nuvel-1 Eurasia-North America pole [4] range from $1.24 \mathrm{~cm} / \mathrm{yr}$ for Survey A centered near $10^{\circ} \mathrm{E}$ to $0.99 \mathrm{~cm} / \mathrm{yr}$ for Survey D centered near $98^{\circ} \mathrm{E}$ (Fig. 2).

The axial valley appears to be continuous across the survey area, but the morphology of the three western survey areas $(\mathrm{A}-\mathrm{C})$ contrasts with the easternmost area (D) (Fig. 3). In survey areas A-C, the ridge is characterized by a deep axial rift valley (Fig. 3) similar to those observed at other slowspreading ridges $[20,21]$. The rift valley is $15-20$ $\mathrm{km}$ wide and 1500-1800 m deeper than surrounding rift flanks in the three western surveys. Maximum depths on most profiles across the axis are between $4600 \mathrm{~m}$ and $4800 \mathrm{~m}$, but locally exceed $5000 \mathrm{~m}$ within each of the three surveys. A bathymetric map of a short portion of the rift axis near $0^{\circ} \mathrm{E}$ published by Jokat et al. [18] shows axial depths of 4000$4350 \mathrm{~m}$. Gakkel Ridge axial depths are consistently deeper than observed on the MAR where the maximum depth normally is in the range of 3500-4000 $\mathrm{m}$ and only rarely reaches $4500 \mathrm{~m}$ depth [22-25]. The Gakkel Ridge rift flanks in the three western surveys are at a depth of about $3200 \mathrm{~m}$, several 

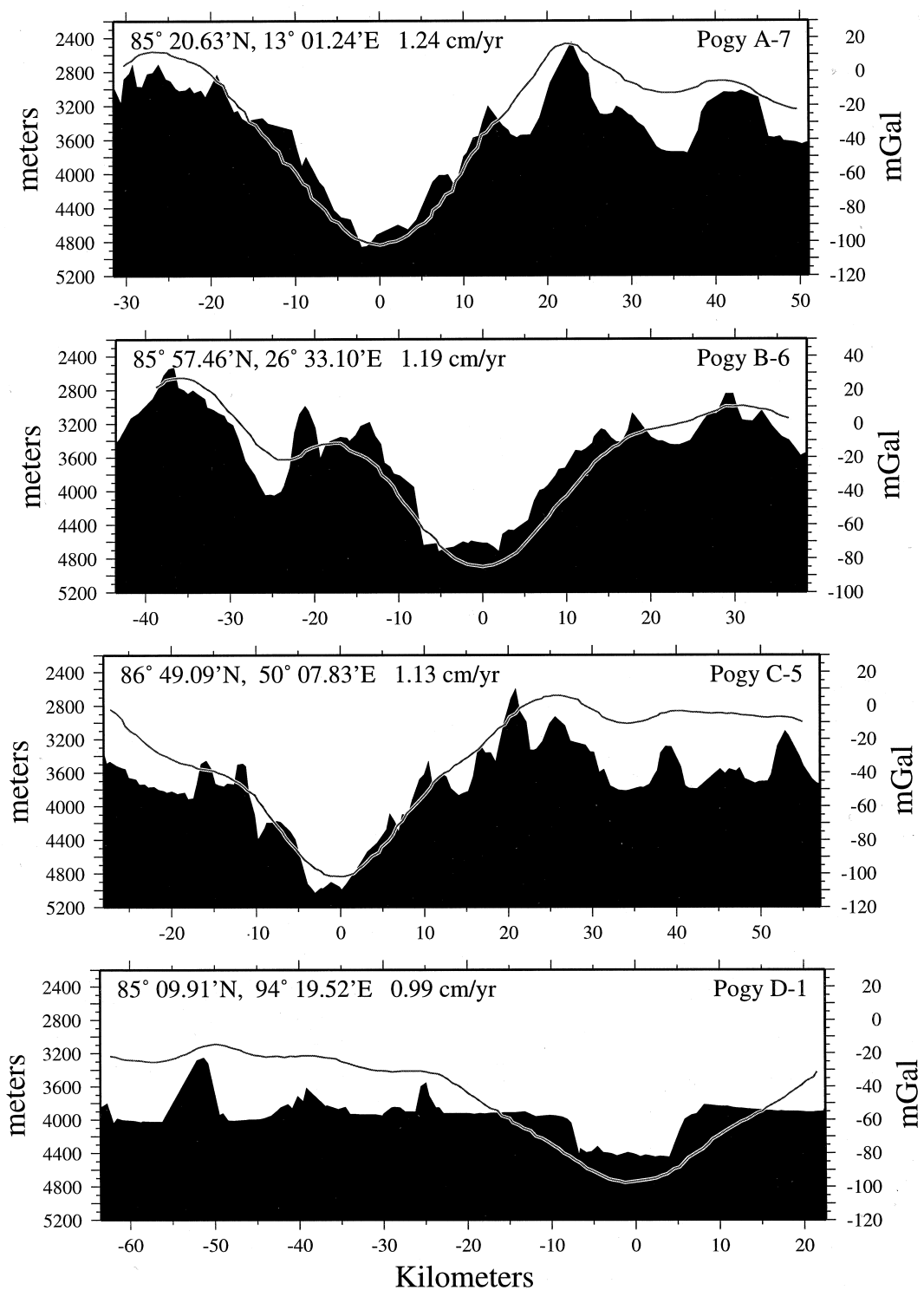

Fig. 3. Representative bathymetry and free-water gravity profiles from each of the four survey areas on the crest of the Gakkel Ridge (Fig. 2). Each profile is projected perpendicular to the local trend of the ridge with the southern (Nansen) basin to the right and the northern (Amundsen) basin the left. The origin for each profile, taken as the minimum gravity value over the ridge axis, is noted on the profile as is the local spreading rate determined from the Nuvel 1 pole [4].

hundred meters deeper than typically observed at faster-spreading ridges $[21,26]$. Individual ridges and troughs can be correlated between tracks, revealing a lineated fabric of ridge-parallel abyssal hills. The bathymetry is very blocky with large scarps with relief of up to $1400 \mathrm{~m}$ common not only at the axial valley, but also on the ridge flanks (Fig. 3). Fault bounded troughs with relief of over $1000 \mathrm{~m}$, reaching depths of over $4000 \mathrm{~m}$ are observed on the ridge flanks in all three of the western surveys.

Free-water gravity anomalies reflect the morphology. The rift valley is associated with a large, continuous negative gravity anomaly. Local gravity maxima occur over the flanking rift mountains. 
Anomalies over the rift valley have peak-to-trough amplitudes of $85-150 \mathrm{mGal}$ throughout the three survey areas. Gravity anomalies over the axis of the MAR are generally in the range of $50-90 \mathrm{mGal}$ [25,27-30]. Even though the bathymetric relief of the rift valley is similar, the gravity anomalies over the Gakkel Ridge rift valley are 1.5 to 2 times those found at faster-spreading portions of the MAR.

Subdued bathymetric relief characterizes the easternmost Survey D region as the result of sedimentation that has buried the ridge flanks to a depth of $4000 \mathrm{~m}$ (Fig. 3, profile D1). The ridge axis is marked a continuous, several hundred meter deep trough which appears to be floored by disturbed sediments. The ridge flanks are significantly deeper than in the west. Only the peaks of the ridge flank topography protrude above the $4000 \mathrm{~m}$ level of the sediment fill. In spite of its subdued morphologic expression, the ridge axis of the eastern Gakkel Ridge is well expressed in the magnetic [31] and gravity anomalies. The ridge axis is marked by a relative free-water gravity low with an amplitude of over $70 \mathrm{mGal}$ throughout the survey area, implying the presence of a large buried rift valley.

The location of the ridge axis in survey area $\mathrm{D}$ based on our bathymetry and gravity data is slightly south of the axial magnetic anomaly mapped by aeromagnetic data (Fig. 2). An unusually high drift rate was observed for the sub's inertial guidance system during the transit from Survey C to Survey D which appears to be the cause of this discrepancy. The ridge axis position shown in Fig. 2 was determined from the bathymetry and gravity profiles and is probably mislocated relative to the independently navigated magnetic data.

\section{Gravity modeling of crustal thickness and density}

The ridge axis at the Gakkel Ridge is unusually deep. The gravity anomalies over the axis are significantly larger in amplitude than at other ridges with similar topographic relief, suggesting that the crust is either atypically dense or thin. This hypothesis can be quantitatively tested by using a simple model for the crust and systematically varying the crustal thickness and density to find parameters that best reproduce the observed gravity anomalies. Since the bathymetry data available to us are individual narrow-beam echo sounder lines rather than swath-bathymetry, a threedimensional gravity model is not feasible. Instead we did two-dimensional modeling using profiles projected perpendicular to the ridge axis. Gravity calculations were carried out at the projected location and depth of the submarine gravity measurements.

Calculations were carried out for four profiles across the Gakkel Ridge for which the assumption of two-dimensionality appears valid from comparison to adjacent profiles. By using profiles where bathymetric features can be readily correlated with adjacent profiles $15-20 \mathrm{~km}$ distant, we are also assured that the modeled profiles are from within rather than at the ends of second-order segments. In order to demonstrate the utility of our method, we also modeled a profile from $26^{\circ} 16^{\prime} \mathrm{S}$ on the MAR where the total spreading rate is $3.56 \mathrm{~cm} / \mathrm{yr}$.

There are three main contributions to the observed free-water gravity anomalies over the ridge crest: bathymetric relief, relief on the Moho and changes in the upper mantle density structure resulting from cooling of the mantle with age of the lithosphere. We assumed a constant thickness, constant density crust for the calculations. The model Moho surface therefore exactly follows the bathymetric relief. The steps involved in this procedure are analogous to those involved in calculating a residual mantle Bouguer anomaly, except that we systematically vary the crustal thickness and density to determine combinations which minimize the residual anomaly.

The thermal effect was modeled using the passive asthenospheric flow model of Phipps Morgan and Forsyth [32]. Calculation of the thermal contribution to the gravity anomalies requires three-dimensional bathymetry to constrain the influence of fracture zones on the plate thermal structure. The geometry of the plate boundary is well mapped at $26^{\circ} \mathrm{S}$ [33], so we were able to include the actual plate geometry in the thermal calculation. Our calculated thermal contribution agrees with a profile taken from the thermal model of Blackman and Forsyth [33] (their fig. 4). The segmentation of the Gakkel Ridge is not well defined, although aeromagnetic and seismicity data suggest the lack of large transforms near our survey areas. For the thermal calculations, we therefore assumed a linear ridge axis. 
The contribution of the different components to the gravity anomalies is illustrated in Fig. 4 for both the Mid-Atlantic Ridge profile and Gakkel Ridge profile B6 (Fig. 2). The same average crustal density $\left(2700 \mathrm{~kg} / \mathrm{m}^{3}\right)$ was used for both profiles. Fig. 4 shows that the thermal contribution to the observed gravity anomalies is greatly reduced at the extremely slow spreading rates of the Gakkel Ridge.

Free-water anomalies were calculated by combining the thermal gravity contribution with the gravity effects of the bathymetric relief and relief on the Moho. Model gravity anomalies were calculated for a range of average crustal densities from $2500 \mathrm{~kg} / \mathrm{m}^{3}$ to $3300 \mathrm{~kg} / \mathrm{m}^{3}$ and crustal thicknesses of $1 \mathrm{~km}$ to 10 $\mathrm{km}$. The misfit between the observed and calculated free-water gravity anomalies were determined for each combination of crustal thickness and density, using the mean square difference between the two profiles as the measure of the misfit.

The results of our modeling are shown in Fig. 5. By contouring the misfit as a function of density and crustal thickness, a minimum misfit can be observed which defines the range of acceptable density/thickness pairs. For each profile, the lower panel shows a plot of the misfit parameter as a function of crustal thickness and crustal density. A zone of crustal density and thickness pairs giving nearly equivalent fits to the observed gravity is shaded. Within that region, a star marks a combination of crustal thickness and density for which the calculated gravity anomalies are compared with the observed free-water anomalies in the upper panel.

Fig. 5a shows the results for the Mid-Atlantic Ridge profile from $26^{\circ} 16^{\prime} \mathrm{S}$. The range of optimum solutions consist of crustal thicknesses greater than $6 \mathrm{~km}$ and crustal densities of $2700-2900 \mathrm{~km} / \mathrm{m}^{3}$. Acceptable solutions exist for crustal thicknesses of as low as $4.5 \mathrm{~km}$, but these require that the average crustal density be in the range of 2500-2600 $\mathrm{kg} / \mathrm{m}^{3}$. The estimate of crustal thickness in the range of $6-7 \mathrm{~km}$ is compatible with observations $[9,11]$, supporting the validity of this procedure.

Fig. 5b,c show model results for two profiles from the Gakkel Ridge. These two profiles bracket our model results, representing the maximum and minimum crustal thickness found consistent with the observed bathymetry and gravity. For profile B6 (Fig. 5b) which gave the maximum possible crustal thicknesses, crustal thicknesses of up to $5 \mathrm{~km}$ are allowed, but only if the average density is $2900 \mathrm{~km} / \mathrm{m}^{3}$. If the average crustal density is less than $2850 \mathrm{~kg} / \mathrm{m}^{3}$, then the range of acceptable crustal thicknesses is between 2 and $4 \mathrm{~km}$. The gravity anomalies for profile C5 (Fig. 5c) can only be matched for crustal thicknesses of less than $1.5 \mathrm{~km}$ unless the average crustal density is greater than $3000 \mathrm{~kg} / \mathrm{m}^{3}$.

The misfit is greater for profile C5 than for the other profiles. Comparison with adjacent profiles shows that the shallow ridges between kilometers 17 and 28 on the projected profile are not truly twodimensional and that their gravity effect is therefore overestimated in the modeling. Even allowing for this, it is not possible, for reasonable crustal densities, to reproduce the amplitude of the gravity anomaly over the ridge axis if the crustal thickness is more than a few kilometers.

The range of acceptable solutions for all of the profiles from the Gakkel Ridge is quite different than for the MAR profile and implies a significantly thinner crust than found on the MAR. Large lateral density contrasts at shallow depth are required to model the observed gravity anomalies at the Gakkel Ridge axis. These density contrasts can be produced by assuming either thin crust or dense crust. If the crustal thickness is assumed to be in the range of 6-8 km typical of faster spreading ridges, then it is not possible to match the amplitude of the gravity anomalies observed over the Gakkel Ridge axis unless the average crustal density is greater than $3000 \mathrm{~kg} / \mathrm{m}^{3}$.

\section{Discussion}

Our estimate of 1-4 km, thick crust at the Gakkel Ridge based on gravity anomalies is considerably less than seismic determinations of $6-7 \mathrm{~km}$ thick crust characteristic of oceanic crust in most settings [10-12,34]. It is consistent with the limited seismic refraction data available from the Arctic. Seismic refraction lines in the Eurasian Basin are concentrated in the very westernmost portion of the basin, north of Greenland and Svalbard, mainly to the west of $0^{\circ} \mathrm{E}$ $[35,36]$, sampling only a small portion of the fastest spreading part of the ridge. Away from the volcanic Yermak and Morris Jesup Plateaus [17], almost all of 

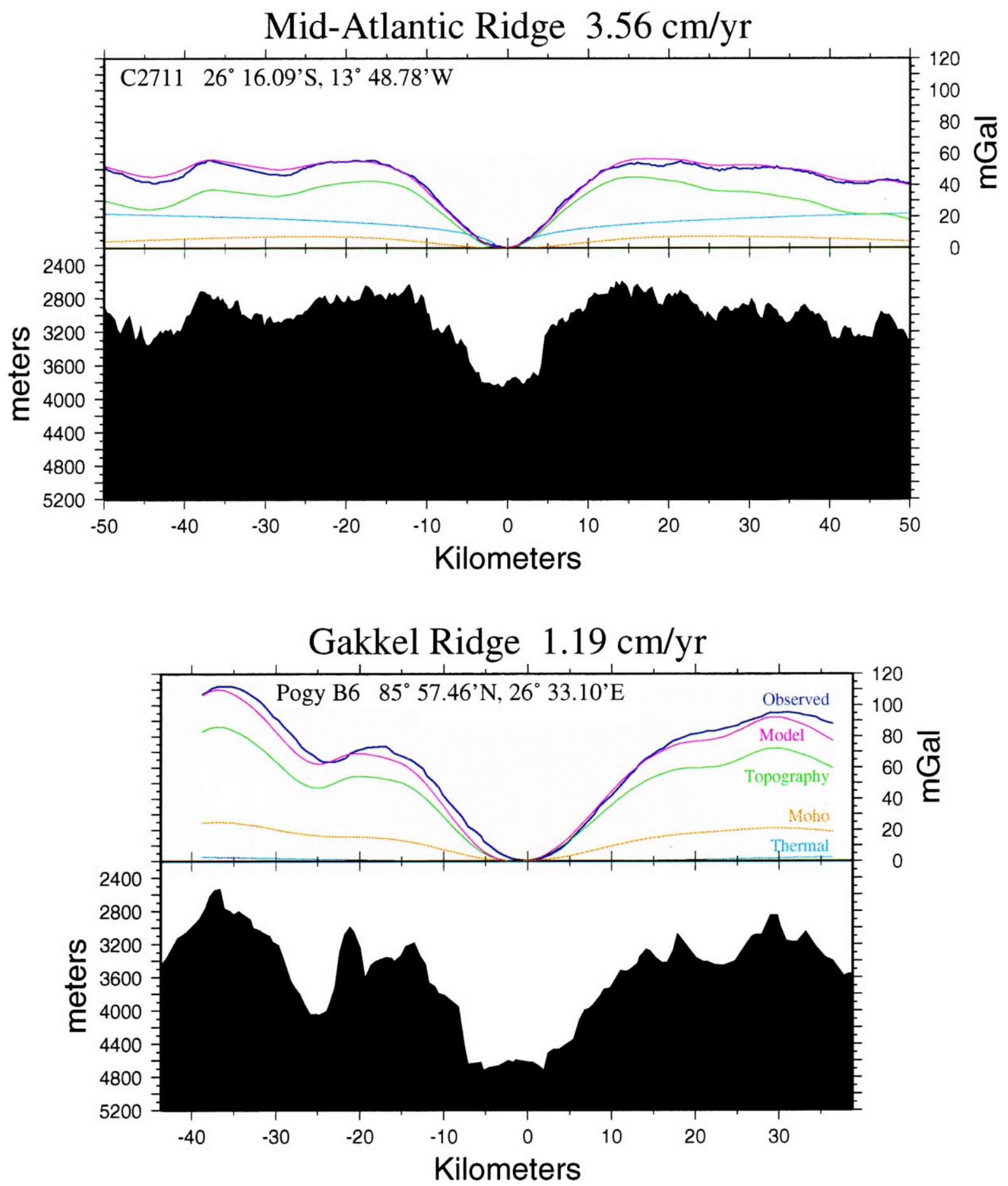
these lines show a thin, 2-4 km-thick oceanic crust [37-39]. Only two refraction lines, both near $84^{\circ} \mathrm{N}$, $7^{\circ} \mathrm{W}$, have been interpreted as showing a thicker $6-8$ $\mathrm{km}$-thick crust $[37,40]$. It is perhaps significant that the thicker crustal determinations were made in an area referred to as the "Yermak H-Zone" by Feden et al. [17] which is characterized by a shallower ridge axis (rift flanks at $\sim 2000 \mathrm{~m}$ depth) $[37,40]$ and higher amplitude magnetic anomalies [2,17,37] than found elsewhere on the Gakkel Ridge.

Bown and White [9] compiled global oceanic crustal thickness data from areas away from hot spots and back-arc basins. They found that crustal thicknesses are in a narrow range of $7 \pm 1 \mathrm{~km}$ for total spreading rates greater than about $1.5 \mathrm{~cm} / \mathrm{yr}$, but that thinner (2-5 km thick) crust becomes common at slower spreading rates. One difficulty with the data available to Bown and White [9] is that almost all of the crustal thickness data from slow spreading oceanic crust is either from the crust created immediately following continental rifting (mainly from the Atlantic margin of Iberia) or from a dying ridge (in particular from the axial region of the Labrador Sea). It is not certain that the thin crust observed in those locations represents an equilibrium situation. The presence of very thin oceanic crust along much of the length of the Gakkel Ridge confirms that thin crust can be created by steady state seafloor spreading at extremely low spreading rates $(<1.2 \mathrm{~cm} / \mathrm{yr})$.

The horizontal mass flux of seafloor spreading is sustained by a vertical flux of rising mantle material. The rate of melt production depends on the pressure and thermal gradients with depth. On very slow spreading ridges, the vertical mass flux may be sufficiently slow that conductive cooling is adequate to suppress decompression melting. Reid and Jackson [8] and Bown and White [9] modeled the temperature field and melt generation beneath a mid-ocean ridge by decompression melting resulting from cor- ner flow of a viscous incompressible fluid. Both studies found that the effects of conductive heating are minimal at spreading rates of greater than $3 \mathrm{~cm} / \mathrm{yr}$, but become increasingly important at spreading rates of less than about $2 \mathrm{~cm} / \mathrm{yr}$. Below this spreading rate, conductive cooling drives the top of the melting region beneath the axis deeper, reducing both the melt fraction and the total amount of melt produced. Bown and White [9] calculated that the top of the melting region should be at a depth of 6-12 km for spreading rates greater than $3.0 \mathrm{~cm} / \mathrm{yr}$ and a mantle potential temperature of $1300^{\circ} \mathrm{C}$. For a spreading rate of $1.0 \mathrm{~cm} / \mathrm{yr}$, it is calculated to be below $20 \mathrm{~km}$, resulting in a significant decrease in melt production.

Our estimates of crustal thickness come from the three western surveys located between $7^{\circ} \mathrm{E}$ and $54^{\circ} \mathrm{E}$ (Fig. 2) where the spreading rates are in the range of $1.13-1.24 \mathrm{~cm} / \mathrm{yr}$. We were unable to use the gravity and bathymetry data to estimate crustal thickness for the eastern survey near $95^{\circ} \mathrm{E}$ with a total spreading rate of $\sim 1.0 \mathrm{~cm} / \mathrm{yr}$ because of the sediments which have nearly buried the ridge (Fig. 3). The rift mountains in the eastern survey are deeper than $3800 \mathrm{~m}$ or about $600 \mathrm{~m}$ deeper than in the three western surveys (Fig. 3). A $3 \mathrm{~km}$-thick crust with an average density of $2900 \mathrm{~kg} / \mathrm{m}^{3}$ at a depth of $3200 \mathrm{~m}$ is in local isostatic equilibrium with a $6-\mathrm{km}$ crustal section at a depth of $2600 \mathrm{~m}$, typical of MAR ridge flank depths (Fig. 5a). If the water depth is increased to $3800 \mathrm{~m}$, as observed on the eastern Gakkel Ridge, then the crustal column in equilibrium with the two other columns is only $160 \mathrm{~m}$ thick. This calculation is very approximate, especially given the presence of considerable sediment on the eastern Gakkel Ridge flanks. However, it does demonstrate that the crustal thickness of the eastern portion of the Gakkel Ridge may be vanishingly small.

The thin crust of the Gakkel Ridge and the extensive large-scale faulting (Fig. 3) raises the possibility

Fig. 4. Technique used in modeling bathymetry and gravity data to determine the acceptable range of crustal thickness and density for profiles across mid-ocean ridge axes. The observed free-air or free-water gravity anomalies were modeled as the sum of three components; the cooling of the mantle away from the ridge axes (calculated using the model of Phipps Morgan and Forsyth [32]), relief on the water/crust interface, and relief on the crust/mantle interface. The contribution of the different components is shown for profiles from the southern Mid-Atlantic Ridge and from the Gakkel Ridge. The same colors are used in both profiles for each component. In both models shown, an average crustal density of $2700 \mathrm{~kg} / \mathrm{m}^{3}$ was used. It can be seen that after summing the thermal and topographic contributions, a much larger Moho contribution is needed to reproduce the gravity anomalies observed on the Gakkel Ridge profile. A crustal thickness of $7 \mathrm{~km}$ for the MAR profile and $3 \mathrm{~km}$ for the Gakkel Ridge profile was required to match the observed gravity profile. 
that mantle peridotites may be commonly exposed as outcrops on the seafloor on the Gakkel Ridge axis and flanks. In the eastern part of the basin, where the ridge axis is exceptionally deep, exposed peridotites may have undergone only very limited amounts of melt extraction, in contrast to peridotites recovered from the MAR and Southwest Indian Ocean. Dick [41] found that peridotites dredged from the Southwest Indian Ridge have undergone "a high degree of melting and severe depletion of basaltic components, reflecting the formation and removal of large volumes of melt (10\%-30\%)" [41], even at largeoffset transforms where thin crust is expected. Dick [41] attributes this to lateral flow of melt toward the centers of ridge segments. The maximum degree of partial melting inferred beneath the deep eastern portion of the Gakkel Ridge is significantly less than for the Southeast Indian Ridge [8,9]. Outcrops on the eastern Gakkel Ridge may present an opportunity to sample undepleted MORB-source mantle.

\section{Conclusions}

(1) The Gakkel Ridge, spreading at $0.6-1.3$ $\mathrm{cm} / \mathrm{yr}$, is a well-organized spreading center characterized by a continuous axial rift valley and ridgeparallel abyssal hill morphology on the ridge flanks. In three survey areas between $7^{\circ} \mathrm{E}$ and $54^{\circ} \mathrm{E}$ (total spreading rates of $1.24-1.13 \mathrm{~cm} / \mathrm{yr}$ ), the rift valley is $1500-1800 \mathrm{~m}$ in relief and $15-20 \mathrm{~km}$ wide, similar to what is observed at other mid-ocean ridges characterized by an axial rift valley. The rift valley in these survey areas reaches depths of 4600-5100 $\mathrm{m}$, while the flanking rift mountains are generally at depths of 3000-3200 m (Fig. 3). The Gakkel Ridge axis is about $500 \mathrm{~m}$ deeper than is typical for the axis of the MAR. The ridge flank abyssal hill morphology is very blocky with numerous large scarps and deep fault-bounded troughs, implying that faulting and mechanical extension play a large role in the development of the morphology.

(2) Large amplitude free-water anomalies are observed over the axis of the Gakkel Ridge, with peak-to-trough amplitudes of $85-150 \mathrm{mGal}$. These anomalies are 1.5 to 2 times larger than those observed over portions of the MAR with comparable bathymetric relief. Modeling of the free-water anomalies including the effect of cooling of the mantle away from the ridge axis [32] and varying the crustal thickness and average crustal density implies that for average crustal densities of $2900 \mathrm{~km} / \mathrm{m}^{3}$ or less, crustal thicknesses of less than $4 \mathrm{~km}$ are needed to match the gravity data (Fig. 5). Similar calculations for profiles from the MAR give crustal thicknesses of 6-8 km, consistent with seismic refraction data.

(3) The rift valley in the eastern portion of the Gakkel Ridge, near $95^{\circ} \mathrm{E}$ is largely filled with sediments from the nearby Siberian shelf. In spite of this, the axis is associated with a $70 \mathrm{mGal}$ free-water gravity minimum implying the presence of a large buried rift valley.

Simple isostatic calculations imply that the crustal thickness at the eastern Gakkel Ridge axis is vanishingly thin. The Gakkel Ridge rift mountains at $95^{\circ} \mathrm{E}$ are at a depth of $>3800 \mathrm{~m}$ (Fig. 3), $600 \mathrm{~m}$ deeper than at the Gakkel Ridge axis west of $60^{\circ} \mathrm{E}$ and $>1000 \mathrm{~m}$ deeper than typical for the MAR. The large change in average depth of the Gakkel Ridge east of $60^{\circ} \mathrm{E}$ suggests that a threshold in spreading behavior is passed at a spreading rate of about $1 \mathrm{~cm} / \mathrm{yr}$.

\footnotetext{
Fig. 5. Results of two dimensional modeling to determine the range of crustal thickness and average crustal density pairs which best explain the observed gravity anomalies on profiles across the mid-ocean ridge. The modeling technique is discussed in the text and illustrated in Fig. 4. The crustal thickness and density were systematically varied and the calculated and observed anomalies compared using the mean square difference as the misfit parameter. The lower panel for each profile shows the misfit as a function of crustal density and thickness. For each profile an area of minimum misfit in which the fit to the data is nearly equivalent is shaded. The upper panels show the observed bathymetry and gravity along with modeled gravity for a combination of crustal thickness and density shown with a star on the misfit diagram. The observed gravity anomalies are shown as a heavy line and the calculated anomalies as a lighter line. Profile A is a typical profile across the Mid-Atlantic Ridge and is best fit for crustal densities of $2700-2800 \mathrm{~kg} / \mathrm{m}^{3}$ and crustal thicknesses of 6-8 km. Profiles B and C are from the Gakkel Ridge. Profile B is best fit by crustal densities of $2650-2850 \mathrm{~kg} / \mathrm{m}^{3}$ and crustal thicknesses of $2-4 \mathrm{~km}$. Profile $\mathrm{C}$ requires crustal thicknesses of less than about $1.5 \mathrm{~km}$ to match the gravity anomalies unless the average crustal density is allowed to be more than $3000 \mathrm{~kg} / \mathrm{m}^{3}$. These two profiles represent the maximum and minimum allowable crustal thickness for modeled profiles from the Gakkel Ridge.
} 


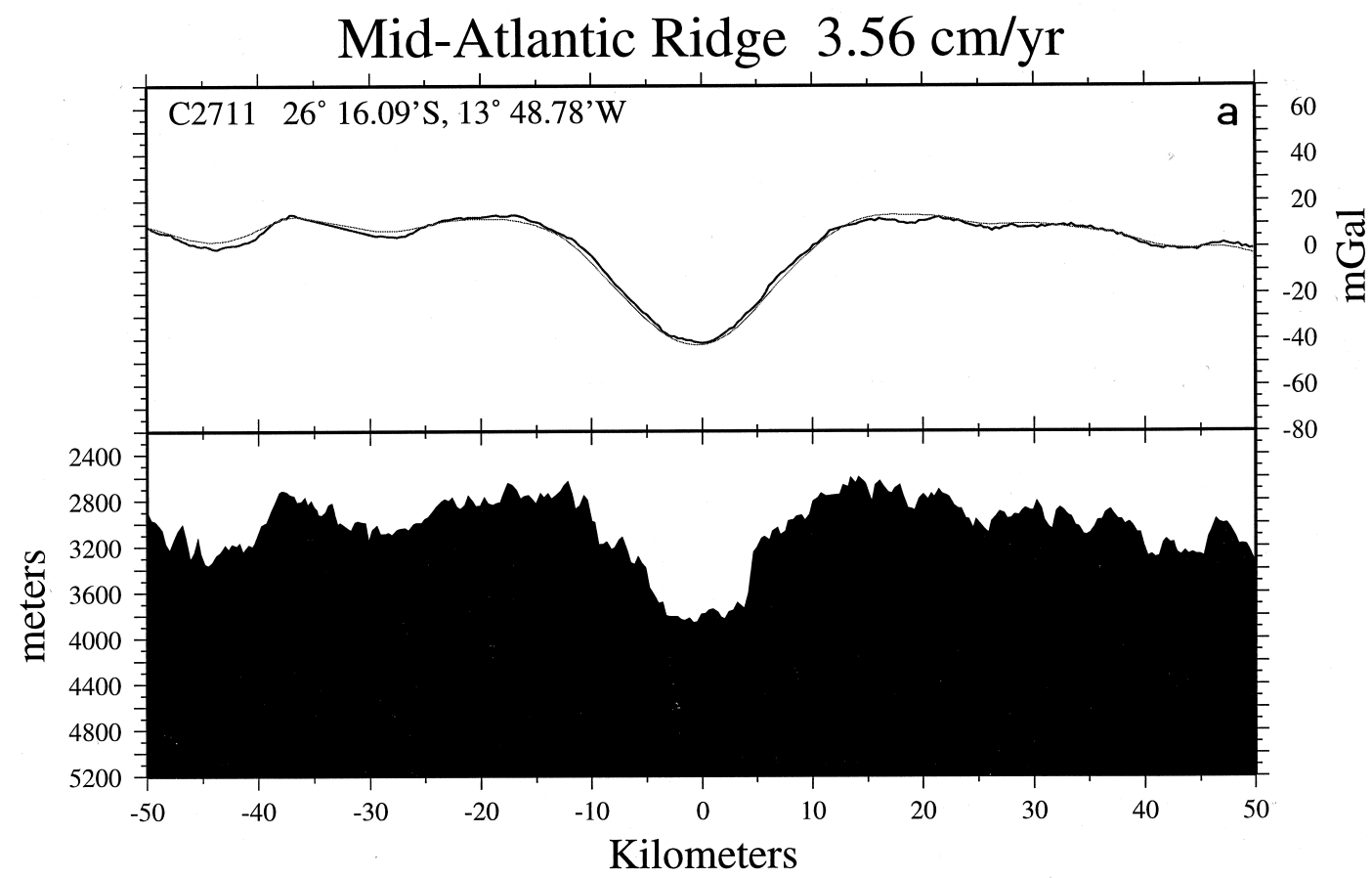

Model Misfit Parameter

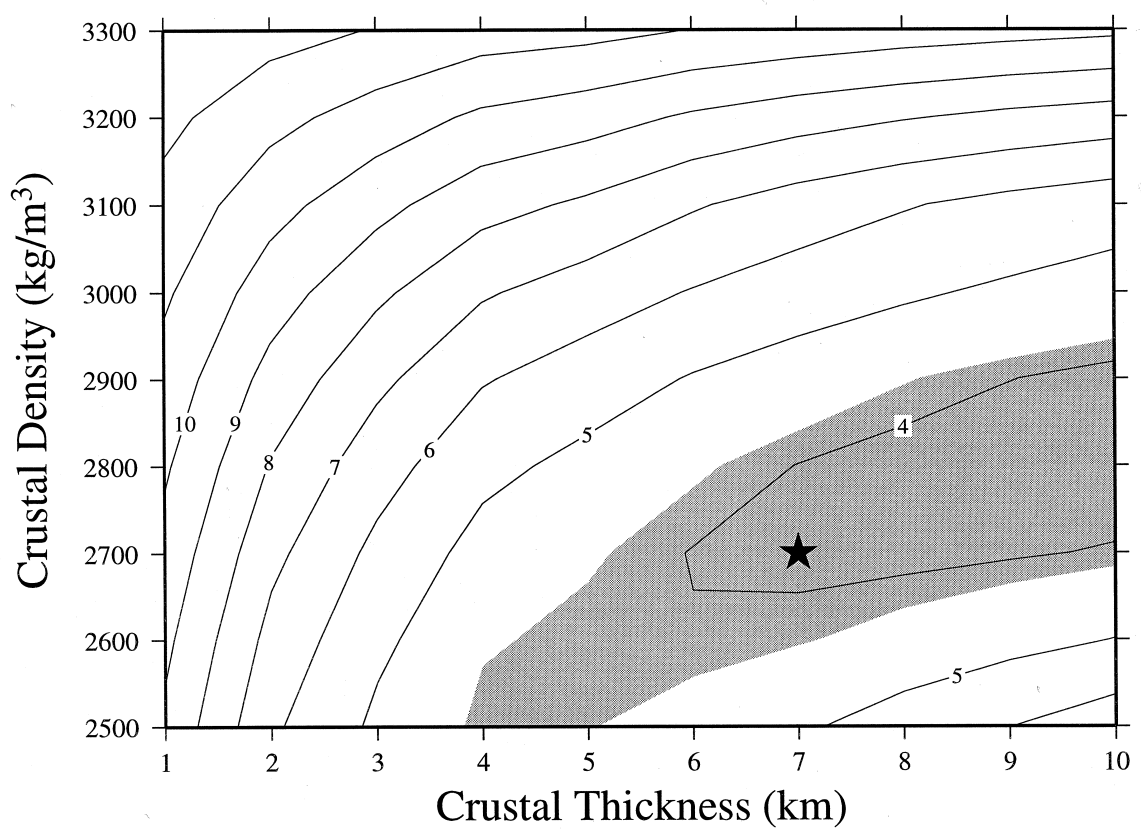



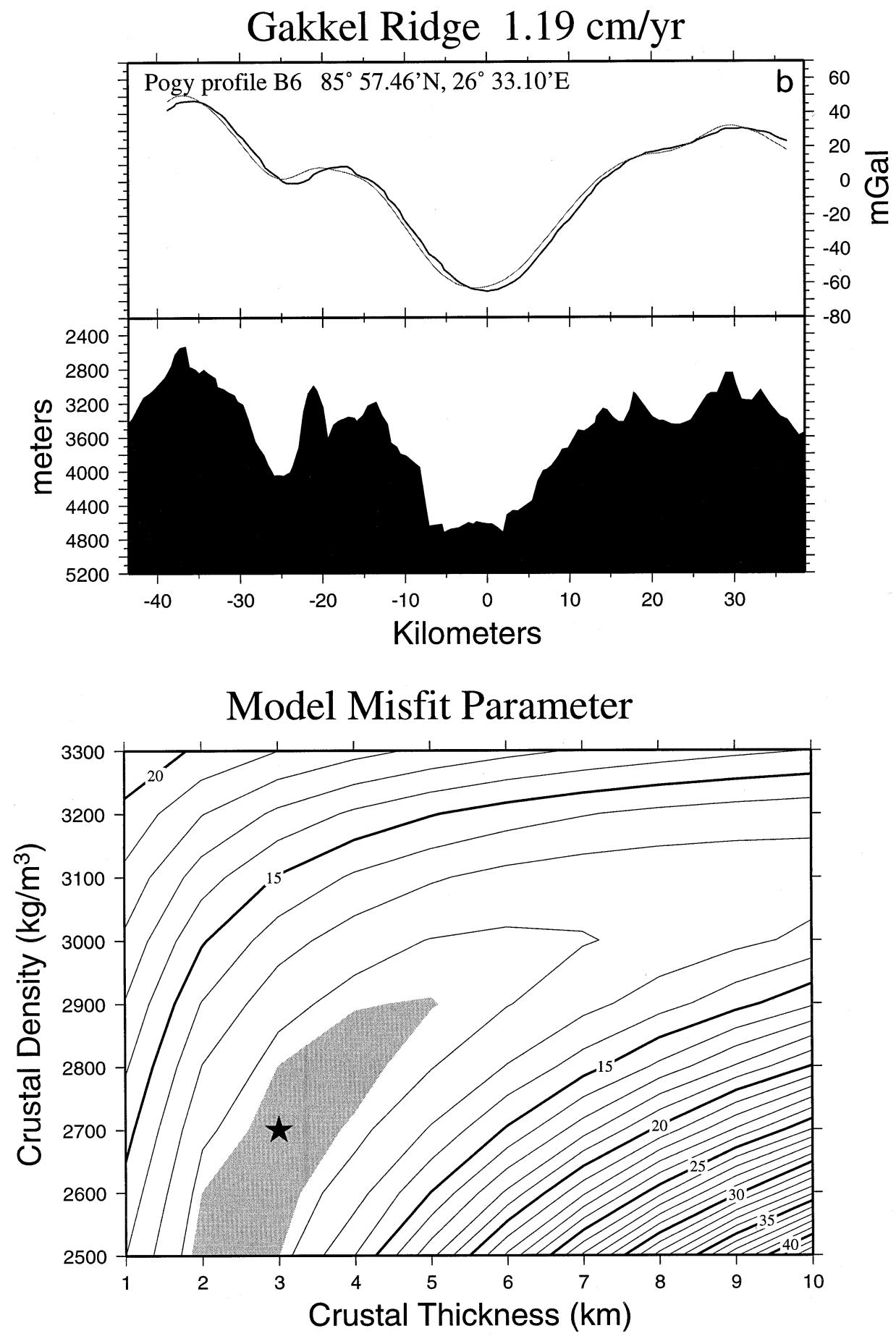

Fig. 5 (continued) 


\section{Gakkel Ridge $1.13 \mathrm{~cm} / \mathrm{yr}$}

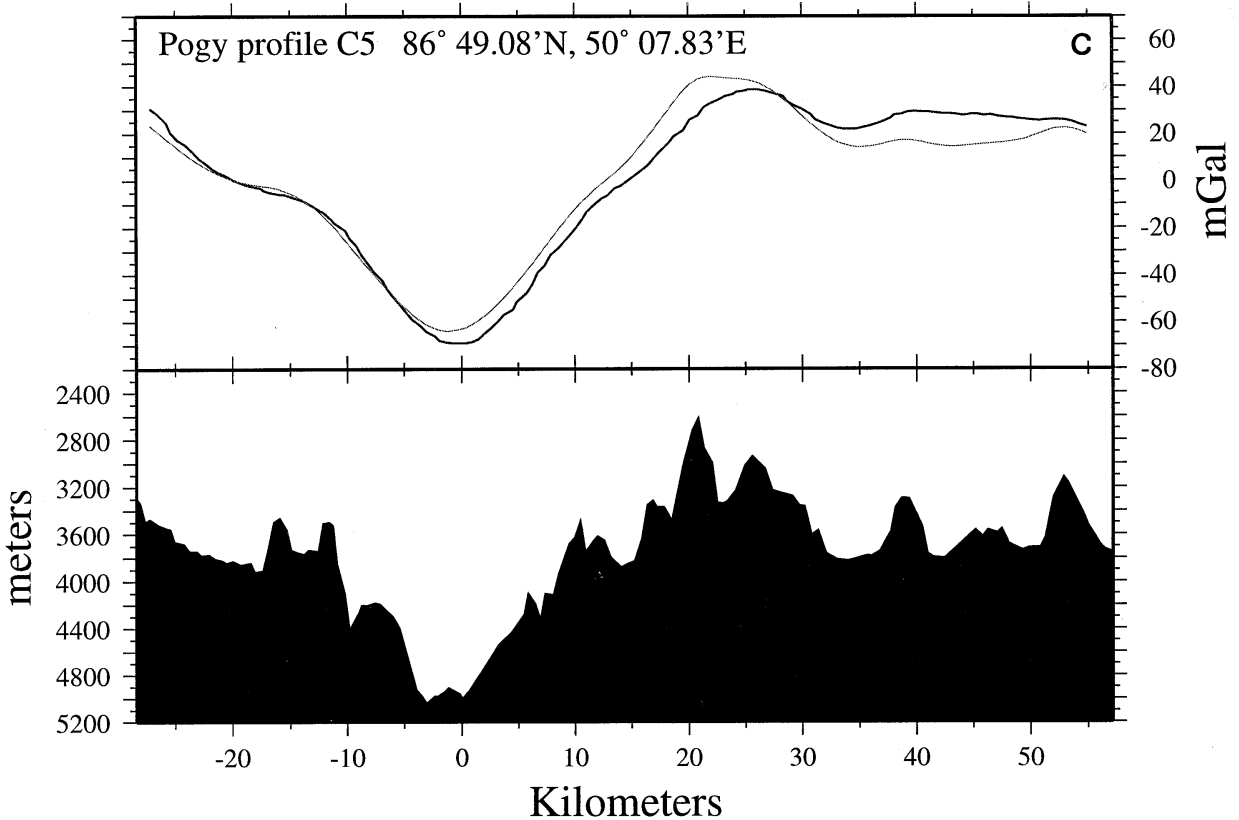

\section{Model Misfit Parameter}

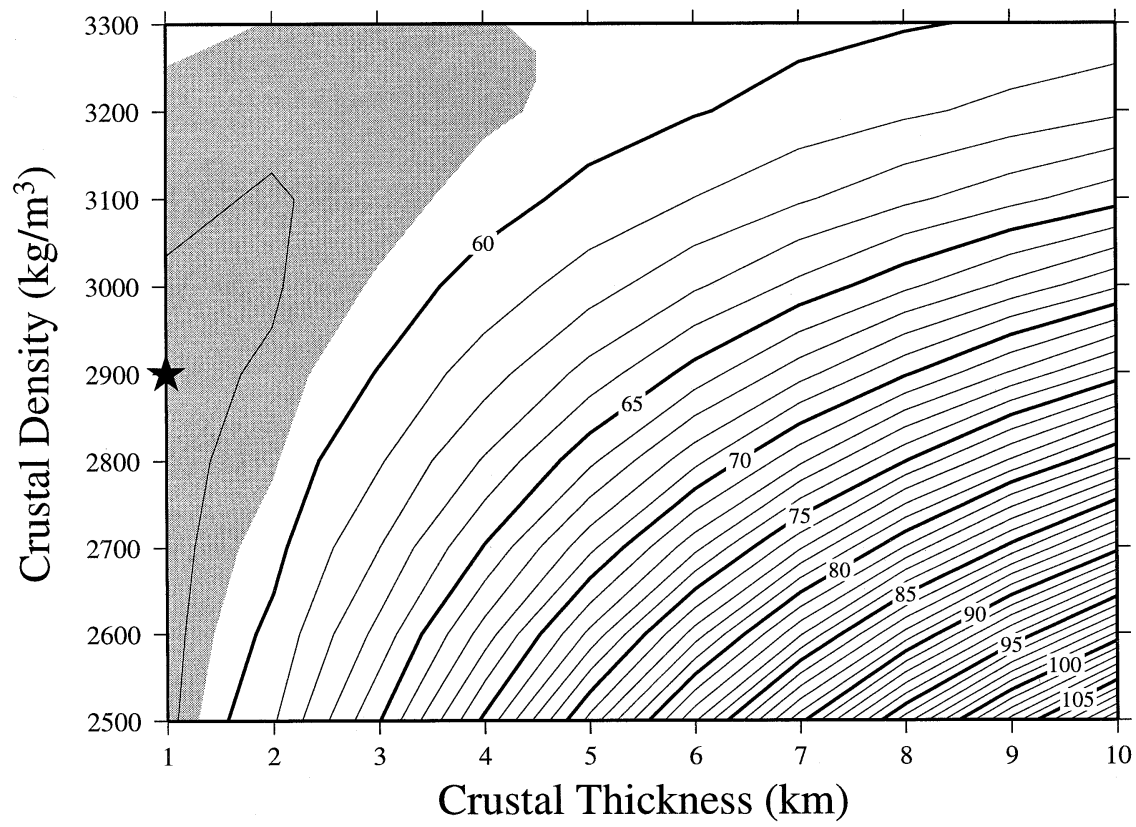

Fig. 5 (continued). 
(4) Deep conductive cooling of the lithosphere may suppress melt production and delivery at very slow spreading rates, restricting volcanic crustal accretion, perhaps by making it episodic. Our gravity modeling results are compatible with thin 'normal' density crust or thicker high-density crust. Thin, normal density crust can be interpreted as a thin layer of basaltic volcanics overlain on the deforming mantle. Thicker, high density crust can be interpreted as a carapace of serpentinized mantle. In either case, it is possible that large areas of the seafloor on the Gakkel Ridge may consist of exposed mantle. [AC]

\section{Acknowledgements}

Each submarine cruise requires the efforts of many individuals, both on the ship and off. First and foremost, we are grateful to the officers and crew of the USS POGY whose enthusiastic support helped this cruise achieve its full potential. We also appreciate the efforts of the Chief Scientist, Ray Sambrotto of Lamont-Doherty Earth Observatory and the Technical Advisor, Jeff Gosset of the Arctic Submarine Laboratory, who kept the cruise moving forward and oversaw the gathering of the data presented here. We thank Dale Chayes who installed and tested the geophysical data acquisition hardware and supertechnician, Jay Ardai of Lamont-Doherty who personally monitored the data acquisition software and hardware and repaired the gravimeter when it suffered a spontaneous gyro failure during the Gakkel Ridge survey. We thank Yngve Kristoffersen, Mathilde Cannat and Bruce Applegate for careful reviews of drafts of this paper. Finally, we remember Marcus Langseth, who helped set up the SCICEX program, and assisted in planning this cruise. Marcus has passed away, but his generous and graceful actions in support of science continue to bear fruit. This work was supported by National Science Foundation grant OPP 96-18436. LDEO contribution No. 5841.

\section{References}

[1] A.F. Grachev, Geodynamics of the transitional zone from the Morna Rift to the Gakkel Ridge, in: Studies in Con- tinental Margin Geology, J.S. Watkins, C.L. Drake (Eds.), Am. Assoc. Petrol. Geol. Mem. 34, Tulsa, OK, 1982, pp. 103-113.

[2] P.R. Vogt, P.T. Taylor, L.C. Kovacs, G.L. Johnson, Detailed aeromagnetic investigation of the Arctic Basin, J. Geophys. Res. 84 (1979) 1071-1089.

[3] A.F. Grachev, A.M. Karasik, Sea-floor spreading and tectonics of the Eurasia Basin; Geotectonic implications to the prospects of mineral resources on the Arctic shelf (in Russian), Nauchno-Issled. Inst. Geol. Arkt. Tr. (1974) 1933.

[4] C. DeMets, R.G. Gordon, D.F. Argus, S. Stein, Current plate motions, Geophys. J. Int. 101 (1990) 425-478.

[5] R.L. Coles, P.T. Taylor, Magnetic anomalies, in: The Arctic Ocean Region, vol. L, A. Grantz, G.L. Johnson, J.F. Sweeney, (Eds.), Geological Society of America, Boulder, CO, 1990, pp. 119-132.

[6] J. Verhoef, R. Macnab, W.R. Roest, Magnetic anomaly map of the Arctic north of $64^{\circ}$, Geological Survey of Canada, 1995.

[7] S. Laxon, D. McAdoo, Arctic Ocean gravity field derived from ERS-1 satellite altimetry, Science 265 (1994) 621624.

[8] I. Reid, H.R. Jackson, Oceanic spreading rate and crustal thickness, Mar. Geophys. Res. 5 (1981) 165-172.

[9] J.W. Bown, R.S. White, Variation with spreading rate of oceanic crustal thickness and geochemistry, Earth Planet. Sci. Lett. 121 (1994) 435-449.

[10] R.W. Raitt, The crustal rocks, in: The Sea, vol. 3, M.N. Hill (Ed.), Wiley-Interscience, New York, 1963, pp. 85-102.

[11] Y.J. Chen, Oceanic crustal thickness versus spreading rate, Geophys. Res. Lett. 8 (1992) 753-756.

[12] R.S. White, D. McKenzie, R.K. O'Nions, Oceanic crustal thickness from seismic measurements and rare earth element inversions, J. Geophys. Res. 97 (1992) 19683-19715.

[13] D. Abbott, Statistics of fracture zones, subduction of ridges, and the composition of ophiolite, Eos (Trans AGU) 69 (1987) 408, abst..

[14] R.S. Dietz, G. Shumway, Arctic Basin geomorphology, Geol. Soc. Am. Bull. 72 (1961) 1319-1330.

[15] G.L. Johnson, B.C. Heezen, The Arctic Mid-Ocean Ridge, Nature 215 (1967) 724-725.

[16] G.L. Johnson, Morphology of the Eurasian Arctic Basin, Polar Rec. 14 (1969) 619-628.

[17] R.H. Feden, P.R. Vogt, H.S. Fleming, Magnetic and bathymetric evidence for the 'Yermak hot spot' northwest of Svalbard in the Arctic Basin, Earth Planet. Sci. Lett. 44 (1979) 18-38.

[18] W. Jokat, E. Weigelt, Y. Kristoffersen, T. Rasmussen, T. Schöne, New geophysical results from the south-western Eurasian Basin (Morris Jessup Rise, Gakkel Ridge, Yermak Plateau) and the Fram Strait, Geophys. J. Int. 123 (1995) 601-610.

[19] R.E. Bell, A.B. Watts, Evaluation of the BGM-3 sea gravity meter system onboard RIV Conrad, Geophysics 51 (1986) 1480-1493.

[20] K.C. Macdonald, The crest of the Mid-Atlantic Ridge: 
Models for crustal generation processes and tectonics, in: The Western North Atlantic Region, vol. M, P. Vogt, B. Tucholke (Eds.), Geological Society of America, Boulder, CO, 1986, pp. 51-68.

[21] A. Malinverno, Transition between a valley and a high at the axis of the mid-ocean ridges, Geology 21 (1993) 639642.

[22] S. LeDouaran, J. Francheteau, Axial depth anomalies from 10 to $50^{\circ} \mathrm{N}$ along the Mid-Atlantic Ridge: correlation with other mantle properties, Earth Planet. Sci. Lett. 54 (1981) $29-47$.

[23] J.C. Sempere, G.M. Purdy, H. Schouten, Segmentation of the Mid-Atlantic Ridge between $24^{\circ} \mathrm{N}$ and $30^{\circ} 40^{\prime} \mathrm{N}$, Nature 344 (1990) 427-431.

[24] J.C. Sempere, J. Lin, H.S. Brown, H. Schouten, G.M. Purdy, Segmentation and morphologic variations along a slow-spreading center: The Mid-Atlantic Ridge $\left(24^{\circ} 00^{\prime} \mathrm{N}-30^{\circ} 40^{\prime} \mathrm{N}\right)$, Mar. Geophys. Res. 15 (1993) 153200.

[25] G.A. Neumann, D.W. Forsyth, The paradox of the axial profile: Isostatic compensation along the axis of the MidAtlantic Ridge?, J. Geophys. Res. 98 (1993) 17891-17910.

[26] C. Small, A global analysis of mid-ocean ridge axial topography, Geophys. J. Int. 116 (1994) 64-84.

[27] B.Y. Kuo, D.W. Forsyth, Gravity anomalies of the ridgetransform system in the south Atlantic between 31 and $34.5^{\circ} \mathrm{S}$ : Upwelling centers and variations in crustal thickness, Mar. Geophys. Res. 10 (1988) 205-232.

[28] E. Morris, R.S. Detrick, Three-dimensional analysis of gravity anomalies in the Mark area, Mid-Atlantic Ridge, $23^{\circ}$ N, J. Geophys. Res. 96 (1991) 4355-4366.

[29] R.S. Detrick, H.D. Needham, V. Renard, Gravity anomalies and crustal thickness variations along the Mid-Atlantic Ridge between $33^{\circ} \mathrm{N}$ and $40^{\circ} \mathrm{N}$, J. Geophys. Res. 100 (1995) 3767-3787.

[30] J.E. Pariso, J.C. Sempere, C. Rommevaux, Temporal and spatial variations in crustal accretion along the Mid-Atlantic Ridge $\left(29^{\circ} \mathrm{N}-31^{\circ} \mathrm{N}\right)$ over the last 10 m.y.: Implications from a three-dimensional gravity study, J. Geophys. Res. 100 (1995) 17781-17794.
[31] L.C. Kovacs, C. Bernero, G.L. Johnson, R.H. Pilger, S.P. Srivastava, P.T. Taylor, G.E. Vink, P.R. Vogt, Residual Magnetic Anomaly Chart of the Arctic Ocean Region, Geological Society of America, Boulder, CO, 1985.

[32] J. Phipps Morgan, D.W. Forsyth, Three-dimensional flow and temperature perturbations due to a transform offset: Effects on oceanic crustal and upper mantle structure, J. Geophys. Res. 93 (1988) 2955-2966.

[33] D.K. Blackman, D.W. Forsyth, Isostatic compensation of tectonic features of the Mid-Atlantic Ridge: $25-27^{\circ} \mathrm{S}, \mathrm{J}$. Geophys. Res 96 (1991) 11741-11758.

[34] N.I. Christensen, M.N. Salisbury, Structure and composition of the lower oceanic crust, Rev. Geophys. 13 (1975) 57-86.

[35] H.R. Jackson, D.A. Forsyth, J.K. Hall, A. Overton, Seismic reflection and refraction, in: The Arctic Ocean Region, vol. L, A. Grantz, L. Johnson, J.F. Sweeney (Eds.), Geological Society of America, Boulder, CO, 1990, pp. 153-170.

[36] Y. Kristoffersen, Eurasia Basin, in: The Arctic Ocean Region, vol. L, A. Grantz, L. Johnson, J.F. Sweeney (Eds.), Geological Society of America, Boulder, CO, 1990, pp. $365-378$.

[37] H.R. Jackson, I. Reid, R.K.H. Falconer, Crustal structure near the Arctic Mid-Ocean Ridge, J. Geophys. Res. 87 (1982) 1773-1783.

[38] G.L. Duckworth, A.B. Baggeroer, H.R. Jackson, Crustal structure measurements near FRAM II in the Pole Abyssal Plain, Tectonophysics 89 (1982) 172-215.

[39] G.L. Duckworth, A.B. Baggeroer, Inversion of refraction data from the Fram and Nansen Basins of the Arctic Ocean, Tectonophysics 114 (1985) 55-102.

[40] Y. Kristoffersen, E.S. Husebye, H. Bungum, S. Gregersen, Seismic investigations of the Nansen Ridge during the Fram 1 experiment, Tectonophysics 82 (1982) 5768.

[41] H.J.B. Dick, Abyssal peridotites, very slow spreading ridges and ocean ridge magmatism, in: Magmatism in the Ocean Basins, A.D. Saunders, M.J. Norrey (Eds.), Geol. Soc. London Spec. Publ. 42 (1989) 71-105.

[42] W.J. Roest, J. Verhoef, R. Macnab, Magnetic anomaly map north of 64 degrees, Geological Survey of Canada Open file 3281, 1996. 